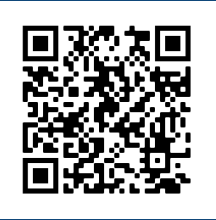

Keywords:

Resource efficiency

Wood processing residues

Wood utilization

Natural resources

Historic:

Received 16/01/2020

Accepted 06/05/2020

Correspondence: emilin.joma.da.silva@uni-hamburg.de
Emilin Joma da Silva ${ }^{1 \mathrm{a}+}$, Goran Schmidt²a, Udo Mantau ${ }^{3 a}$

\section{WOOD RESOURCE BALANCE FOR PLANTATION FORESTS IN BRAZIL: RESOURCES, CONSUMPTION AND CASCADING USE}

DA SILVA, E. J.; SCHMIDT, G.; MANTAU, U. Wood resource balance for plantation forests in Brazil: resources, consumption and cascading use.CERNE, v. 26, n. 2, p.247-255, 2020.

\section{HIGHLIGHTS}

The main sources of wood and wood utilization in Brazil for 2008 and 2018.

Evolution of the cascading use of wood resources in Brazil.

Wood resource balance as a monitoring tool for decision makers.

The plantation forest as main actor for an eco friendlier forest industry.

\section{ABSTRACT}

A resource balance comprises a method to monitor sources and uses of a given material. The wood resource balance analyses origins of wood resources used in the production of semi finished forest products. At the same time, the resource balance helps tracking wood processing residues and its further uses. A primary survey with I I 3 companies was conducted and official statistics were consulted to carry out the first wood resource balance for Brazilian plantation forests. The balance sheets were analysed for 2008 and 20l8. Wood resources consumption increased from 208 to 231 million $\mathrm{m}^{3}$. Wood processing residues volumes had grown by $19 \%$ in the same period. Round wood demand for material use accounted to $66 \%$ in 2018 whilst $99 \%$ of residues were used energetically. The sector's supply and production sides have shown to be in an exceptional balance. An increase on resource efficiency and cascading uses was observed in Brazil during the analysed period. The plantation forests supplied the greater domestic demand for round wood which relieves use pressure on natural forests. 


\section{INTRODUCTION}

The monitoring of wood resources availability and its consumption is of great importance to maintain forest policy in balance with society needs. The wood resource balance (WRB) methodology (Mantau et al., 2010) was conducted in several European countries to understand wood material flows and disclose competition between material and energy uses of wood. The WRB also take the cascading use phenomenon into consideration, once the multiple use of resources by utilizing residues and recovered resources is presented by the balance calculation (Mantau and Blanke, 2016). The cascading use strongly overlaps itself with the circular economy concept since describes actions to increase the resource efficiency and provides a comprehensive knowledge base for improvement in forest and related biobased industries(Jarre et al., 2020). In other words, the cascading use multiplies the benefit from one unit of resource if it is used as a material as long as possible and as a fuel only when further material utilisation is not possible or feasible(Taskhiri et al., 2019). Therfore the cascading use of wood is an important step to achieve sustainability.

Compared to other emerging economies, Brazil has an outstanding forest sector. In 2018 the Brazilian Forestry Industry (IBA), reported a revenue of USD 23.4 billion (BC, 20I9; IBA, 20I9), representing a I.3\% gross domestic product (GDP) share and $6.9 \%$ of the domestic industrial sector. The wood industrial segment in Brazil had emerged in the 1930s and since then especially focusses pulp production. From 1957 onward, this industry had received government subsidies and foreign direct investments leading to growing production (Silva et al., 2015). In 1966, tax incentives for reforestation aimed securing supply safety for pulp and charcoal (Silva et al., 2017). In the 1970s an incentive developed the tropical wood trade in Brazilian border areas (e.g.: Amazon forest region) (Sicsú and Lima, 2013). In 1990 the forest sector invested into export oriented added value products. In the beginning of the 2000 s mature plantation forests attracted international investors. Timberland Investment Management Organizations (TIMOs) functioned as levers expanding plantation areas in Brazil (Silva et al., 20I7). In 2018 the Brazilian plantation forests accounted to $1.2 \%$ of the national territory dominated by Eucalyptus spp. and Pinus spp. (IBGE, 2018a, 20I8b; SFB, 2019).

To date, no WRB was done for Brazil. This resource balance shall support decision makers and government entities on natural resource management. The study presents the WRB as an alternative to constantly monitor wood resources and had considered only plantation forests on its calculation. Data from 2008 and 2018 was compared.

\section{MATERIAL AND METHODS}

\section{The Wood Resource Balance methodology}

The WRB for Brazilian plantation forests was carried out following the categories shown in Table I. Just like in balance sheet accounting, the material and energy use of wood represent the liabilities and shareholder (ownings) on the right side, the wood sources are shown as the assets (debts) on the left. Both volumes are being presented in cubic meter $\left[\mathrm{m}^{3}\right]$ of round wood under bark. In accordance with the Système International, the unit $\mathrm{I} \mathrm{hm}^{3}$ represents a volume of $\mathrm{I}, 000,000 \mathrm{~m}^{3}$.

TABLE I Basic wood resource balance analyses.

\begin{tabular}{|c|c|c|}
\hline Sources & & Uses \\
\hline Round wood & \multirow{5}{*}{ Material } & Sawmill \\
\hline Forest residues & & Plywood \& veneer \\
\hline Bark & & Pulp industry \\
\hline Wood processing residues & & Panel industry \\
\hline Wood outside forest & & Other material uses \\
\hline Waste wood & \multirow{2}{*}{ Energy } & Firewood \\
\hline Recycling & & Wood charcoal \\
\hline
\end{tabular}

Residues are inevitable to different amounts during wood processing due to technical yield restrictions (Saal et al., 2017). Conversion factors were applied to quantify wood processing residues (WPR). The calculated WPR volume was considered to be available as source.

\section{Wood uses}

The round wood consumption figures for plantation forests were gathered from the Brazilian Institute of Geography and Statistics (IBGE). Data regarding round wood consumption from natural forests was collected from the Brazilian Forest Service (SFB). However, natural forests were not integrated in the WRB since species composition, conversion factors and final use are way more complex and systematic data was lacking. Data in consumption of plantation forest round wood for material uses was provided by IBGE. The regarding data was subdivided in two categories: round wood for the pulp industry and round wood for other industries. A further breakdown of round wood consumption in other industries was achieved through information on the production of semifinished forest products published by the Food and Agriculture Organization of the United Nations (FAO). The round wood consumption for manufacturing $\mathrm{I} \mathrm{m}^{3}$ of a semifinished product was calculated with the conversion factors shown in Table 2. Information on round wood consumption for other material uses was obtained from FAO and IBA. 
The round wood volume for energy use (firewood and charcoal) was collected from the Energy Research Office (EPE) in tonnes [t]. The volume of round wood needed for charcoal production was calculated using conversion factor (table 2). IBGE, IBA and EPE published data on charcoal production volumes and a comparison between results was carried out.

TABLE 2 Conversion factors for plantation forests sector in Brazil.

\begin{tabular}{|c|c|c|c|}
\hline \multicolumn{2}{|c|}{ Semi finished product } & \multicolumn{2}{|c|}{ Conversion factor } \\
\hline \multirow{3}{*}{ Cellulose A } & Short fibre & \multirow{6}{*}{$\begin{array}{c}\mathrm{m}^{3} \text { round wood } / \mathrm{t} \\
\text { product }\end{array}$} & 4.85 \\
\hline & Long fibre & & 6.90 \\
\hline & High yield (Pine) & & 1.45 \\
\hline Firewood B & \multirow{2}{*}{ Eucalyptus } & & 1.47 \\
\hline Charcoal B & & & 5.75 \\
\hline Pellets C & WPR (sawmill) & & 1.56 \\
\hline \multirow{3}{*}{ Panels A } & HB (Eucalyptus) & \multirow{6}{*}{$\begin{array}{c}\mathrm{m}^{3} \text { round wood / } \\
\mathrm{m}^{3} \text { product }\end{array}$} & 2.80 \\
\hline & MDF (Pine) & & 2.00 \\
\hline & OSB (Pine) & & 1.60 \\
\hline $\begin{array}{c}\text { Plywood \& } \\
\text { veneer A }\end{array}$ & Pine & & 2.66 \\
\hline \multirow{2}{*}{ Lumber A } & Softwood & & 2.60 \\
\hline & Hardwood & & 3.10 \\
\hline
\end{tabular}

Following the EPE definitions, the wood resources consumption for energy use was divided into three categories (Table 3). Besides firewood and charcoal, information on other wood resource for energy use (e.g. black liquor) was reported. The firewood and charcoal volume for household consumption are presented as "private household". Wood resources burned e.g. in cogeneration plants to provide heat and power for industrial and agricultural purposes were shown as "industry \& farming". Wood resources for electricity generation were presented as "energy producer".

TABLE 3 Energy use categories of wood resources in the WRB Brazil.

\begin{tabular}{cc}
\hline Energy use categories & Assortment \\
\hline Private household & Firewood and charcoal \\
Industry \& farming & Firewood, charcoal, black liquor, pellets and WPR \\
Energy producer & Charcoal, black liquor, and WPR \\
\hline
\end{tabular}

The domestic production of wood pellets was reported by Brazilian Pellets Associates (ABIPEL) (Garcia, 2017). The WRB analysis treated pellets and charcoal as a wood source, and both were considered to be completely used for energy purposes.

\section{Wood sources}

Five different approaches have been chosen to ensure high data reliability:

Potential round wood production was modelled multiplying area in hectare [ha] per mean annual increment (MAl) in $\mathrm{m}^{3} / \mathrm{ha}$. The volume obtained was named "sustained production". Values for plantation area and MAI were obtained with IBGE and IBA.
In addition, potential round wood production was calculated via the SIS software family, developed by EMBRAPA, the Brazilian Agricultural Research Corporation. The software predicts forest growth according to the user input information on forest management practices. The chosen input variables are growth cycle in years, species as well as period and intensity of forest operations, e.g. thinning. The round wood production volume was carried out separately, according tree species (SisEucalipto; SisPelliotti; SisTeca; SisAcacia; (EMBRAPA, 20I2) and named "SIS production".

The results for sustained production and SIS production were compared with the reported round wood consumption informed by IBGE.

National trade data was integrated considering round wood and WPR import and export. Information on trade flows was obtained from the Ministry of Development, Industry and Foreign Trade (MDIC) and is presented in the following sections.

Alternative wood resources named as "waste wood" was investigated. Were considered to be waste wood residues from civil construction, appointed by the Brazilian Public Sanitation and Special Residues Association (ABRELPE). Besides ABRELPE, FAO reported volume of residues occurrence and were considered to be waste wood in this study as well. The assortment ranged from sawmill rejects, slabs, edgings and trimmings, veneer log cores, veneer rejects, sawdust, residues from carpentry production and others. Waste wood from municipal pruning and demolish was not reported consistently and consequently disregarded.

\section{Primary survey}

A quarterly telephonic survey was done with 113 Brazilian forest enterprises from November 2016 to December 2017. Only enterprises sourcing or demanding round wood from plantation forests were selected. The periodic questionnaire requested information on round wood production, wood resources consumption and WPR occurrence. Enterprises with WPR occurrence, were further inquired to specify dimensional characteristics and intended use. Enterprises producing round wood were asked to inform the adopted rotation periods and forest operations (e.g. thinning, clear cut, etc.). The company names were rendered anonymously protecting data privacy.

\section{RESULTS AND DISCUSSION}

\section{Wood resource balance for Brazil}

The global round wood consumption in 2016 was $1,873 \mathrm{hm}^{3}$ of which Brazil participated with 213 
$\mathrm{hm}^{3}$ representing around II \% share (FAO, 20 I8; IBGE, 2018a). In two years, the round wood consumption increased by $7.2 \%$ and reached almost $230 \mathrm{hm}^{3}$ in 2018. The Table 4 presents that plantation forests had increased its round wood production and kept to supply the domestic demand.

The presented round wood volume (sources) is the sum of the recorded round wood consumption. The final sum of the wood resources consumption is higher since the WRB accounted volumes of WPR, charcoal and pellets as wood sources too.

The calculation disclosed that around $50 \%$ of the total round wood consumption happened to be WPR in both years. Round wood consumption by the sawmill industry played an important role in 2008. However, ten years later the lumber production decreased by $19 \%$ and consequently the occurrence of sawmill byproducts was reduced too. In contrast, the pulp industry skyrocketed its round wood consumption by $69 \%$ from 2008 to 2018 and increased the black liquor occurrence as well. This growth had figured a Compound Annual Growth Rate (CAGR) of $5 \%$ in the same period. The panel industry experienced a CAGR of $4 \%$ and played an important role on wood resources consumption increase at the analysed period.

Though the round wood consumption had increased from 2008 to 2018 , firewood and charcoal use had diminished in volume. Wood charcoal production and consumption is widely related to the steel industry in Brazil (IAB, 20I8; Pinto et al., 20I8). Actually, charcoal blast furnaces represent only $1 \%$ of the world's pig iron production, but in Brazil it represents around 30\% (CGEE, 20I0). There are several possible explanations for this particularity. The high productivity of domestic plantation forests and also low operational cost than in northern countries positively contribute for the charcoal use within the steel industry (Piketty et al., 2009). Charcoal had supplied $21 \%$ of the steel industry energy need in 2008, but in the last decade this participation diminished by I4\% (EPE, 2019). This fact has influenced the decrease of the charcoal consumption in Brazil in the analysed period.

No report on pellet production was available for 2008.

The WRB results presented a very similar volume of wood resources consumption for both years. This fact is related to the consumption variation of sawmills, pulp and panel industry and the occurrence of WPR inside each segment. In 2008, the sawmill industry consumed 50.7 $\mathrm{hm}^{3}$ round wood delivering more than $32 \mathrm{hm}^{3}$ WPR. Ten years later, the sawmill industry had reduced its production and consequently WPR volumes dropped by $23 \mathrm{hm}^{3}$. The occurrence of sawmill byproducts decreased from $65 \%$ to $56 \%$ during the analysed period.

\section{Reported round wood sources and uses}

Brazil covers a total land area of 852 million ha (IBGE, 20I7a) of which 488 million ha are natural forests representing $12 \%$ of the global forest cover (FAO, 20 I6; SFB, 2019). Of the total Brazilian forest cover in 2018, the Amazon forest geographically represented $68 \%$ (SFB, 2019). In the same year the Forest Stewardship Council reported 6.7 million ha of certified forest in Brazil, both natural and plantation, however the major part being plantation forest (FSC, 2019). The figure I shows the land use for Brazil in 2018.

Even though plantation forests cover only 1.2 $\%$ of the territory, $85 \%$ of the national round wood consumption was provided by this plantations (SFB, 2018). Natural forests supplied 40.7 million $\mathrm{m}^{3}$, while plantations delivered an impressive $23 \mathrm{I} \mathrm{hm^{3 }}$ of round wood in 2018 (IBGE, 2018a; SFB, 2019).

The calculated round wood production (sustainable production and SIS production) informed an even greater potential supply, as the recorded round wood consumption. The SIS production volume is presented in Table 5 into two different assortments,

TABLE 4 Wood resource balance for Brazil in 2008 and 2018.

\begin{tabular}{|c|c|c|c|c|c|c|c|c|c|}
\hline & \multirow{2}{*}{$\begin{array}{r}\text { Sources } \\
2008 \\
\end{array}$} & & \multirow[b]{2}{*}{2018} & \multicolumn{6}{|c|}{ Uses } \\
\hline & & & & & & & 20 & & \\
\hline $\mathrm{hm}^{3}$ & $\%$ & $\mathrm{hm}^{3}$ & $\%$ & $\mathrm{hm}^{3}$ & $\%$ & $\mathrm{hm}^{3}$ & $\%$ & & \\
\hline Round wood & 208.0 & 60.2 & 229.7 & 66.9 & 50.7 & 14.7 & 41.0 & 11.9 & Sawmill industry \\
\hline Forest residues & 0.0 & 0.0 & 0.0 & 0.0 & 11.8 & 3.4 & 10.8 & 3.1 & Plywood \& veneer \\
\hline Bark & 0.0 & 0.0 & 0.0 & 0.0 & 59.5 & 17.2 & 100.4 & 29.3 & Pulp industry \\
\hline Sawmill by products & 32.8 & 9.5 & 23.1 & 6.7 & 10.0 & 2.8 & 15.4 & 4.5 & Panel industry \\
\hline Other industrial & 19.8 & 5.7 & 21.2 & 6.2 & 1.0 & 0.3 & 1.6 & 0.5 & Other material uses \\
\hline Residues & & & & & 0.0 & 0.0 & 0.7 & 0.2 & Fuel wood producer \\
\hline Black liquor & 29.3 & 8.5 & 41.8 & 12.2 & 42.4 & 12.3 & 33.9 & 9.9 & Private household \\
\hline Charcoal & 55.6 & 16. I & 26.1 & 7.6 & 155.7 & 45.0 & I 14.0 & 33.2 & Industry \& farming \\
\hline Pellets & 0.0 & 0.0 & 1.3 & 0.4 & 14.7 & 4.3 & 25.4 & 7.4 & Energy producer \\
\hline SUM & 345.5 & 100.0 & 343.2 & 100.0 & 345.5 & 100.0 & 43.2 & 100.0 & SUM \\
\hline
\end{tabular}




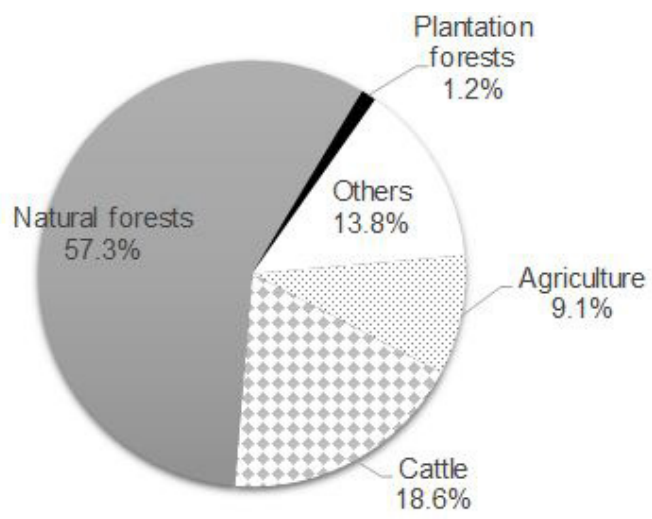

FIGURE I Land use in 2018 in Brazil (IBGE, 20I8b, 20I7b; SFB, 2019).

according to the diameter size $[\varnothing]$ in centimetres $[\mathrm{cm}]$. Since not all plantation forests areas had followed the forest management considered in the calculations (growth cycle, thinning, MAI), the obtained volume is overestimated.

TABLE 5 Harvested round wood volume from natural and plantation forests in 2018 , and the potential round wood production.

\begin{tabular}{cccccccc}
\hline & \multicolumn{3}{c}{ Harvested round wood A } & \multicolumn{2}{c}{$\begin{array}{c}\text { Potential round wood } \\
\text { production }\end{array}$} \\
\cline { 2 - 8 } Species & Natural forests & $\begin{array}{c}\text { Plantation } \\
\text { forests }\end{array}$ & $\begin{array}{c}\text { Sustained } \\
\text { production }\end{array}$ & $\begin{array}{c}\text { SIS } \\
\text { production }\end{array}$ \\
\cline { 2 - 8 } & material energy & material energy & $\varnothing$ in [cm] & $8-25$ & $>25$ \\
\cline { 2 - 8 } & \multicolumn{7}{c}{$\left[\mathrm{hm}^{3}\right]$} \\
Eucalyptus spp. & NA & NA & 94.8 & 85.0 & 269.3 & 217.4 & 41.1 \\
Pinus spp. & NA & NA & 36.3 & 3.4 & 60.5 & 35.3 & 22.6 \\
Other species & II.4 & 29.3 & 2.5 & 4.5 & 3.7 & 0.7 & \\
\hline SUM & 40.7 & 231.3 & 329.8 & 320.8 & & \\
\hline A
\end{tabular}

A (IBGE, 2018a; SFB, 2019); NA: not available

International trade of round wood and WPR was unrepresentative in Brazil. However, the trade of semifinished and finished wood products is a highlight. Table 6 present exported volumes of round wood sourced by plantation forest. The imported volume of round wood and WPR was not reported or negligible.

Even if ABRELPE had informed the municipal solid waste (MSW) volume (78.4 million $\mathrm{t}$ ) and its composition share of $15.6 \%$ considered to be textiles, rubber, leather and wood (ABRELPE, 20I7; IPEA, 20I2a, $2012 \mathrm{~b}, 20 \mathrm{I} 2 \mathrm{c}$ ) the exact proportion of each one of the cited

TABLE 6 Export (FOB) of Eucalyptus spp., Pinus spp. and Tectona grandis round wood in Brazil 2018 (MDIC, 20I8).

\begin{tabular}{cccc}
\hline Species & $\begin{array}{c}\text { Weight } \\
{[\text { million } \mathrm{t}]}\end{array}$ & $\begin{array}{c}\text { Density A } \\
{\left[\mathrm{kg} / \mathrm{m}^{3}\right]}\end{array}$ & $\begin{array}{c}\text { Volume } \\
{\left[\mathrm{hm}^{3}\right]}\end{array}$ \\
\hline Eucalyptus spp. & 342.1 & 425.0 & 0.55 \\
Pinus spp. & 22.7 & 326.5 & 0.05 \\
Tectona grandis & 1.90 & 660.0 & 0.01 \\
\hline
\end{tabular}

A (IPT, n.d.) materials was not available. Consequently, the waste wood coming from MSW was not included in the WRB calculation.

Specific national aspects

The primary survey accounted round wood demand exclusively sourced by plantation forests. The demand informed by the interviewed enterprises represented $48 \%$ of the consumption reported by official statistics in 2017. Table 7 shows the sample composition along with the survey scope. Besides round wood enterprises demanded a mix of other resources, e.g. WPR. Figure 2 presents the WPR share for material uses.

TABLE 7 Export (FOB) of Eucalyptus spp., Pinus spp. and Tectona grandis round wood in Brazil 2018 (MDIC, 2018).

\begin{tabular}{|c|c|c|c|c|}
\hline \multirow[t]{2}{*}{ Segments } & \multirow{2}{*}{$\begin{array}{c}\mathrm{N} \\
\mathrm{A}\end{array}$} & \multicolumn{3}{|c|}{ Round wood } \\
\hline & & $\mathrm{B}$ & C & \\
\hline Pulp industry & 25 & 83.9 & 90.3 & 92.7 \\
\hline Energy use & 10 & 11.0 & 78.9 & 84.8 \\
\hline Panel industry & 10 & 9.8 & 14.4 & 53.8 \\
\hline Sawmill and plywood & 36 & 3.8 & 34.3 & \\
\hline Agriculture \& livestock & 8 & I.I & NA & \\
\hline Other industrial use & 24 & 1.0 & 3.1 & \\
\hline Total & 113 & 110.6 & 221.0 & 231.3 \\
\hline
\end{tabular}

A Results of the primary survey; B Wood consumption for industrial use (IBA, 2019); C Wood removals (IBGE, 20I8a) NA: not available

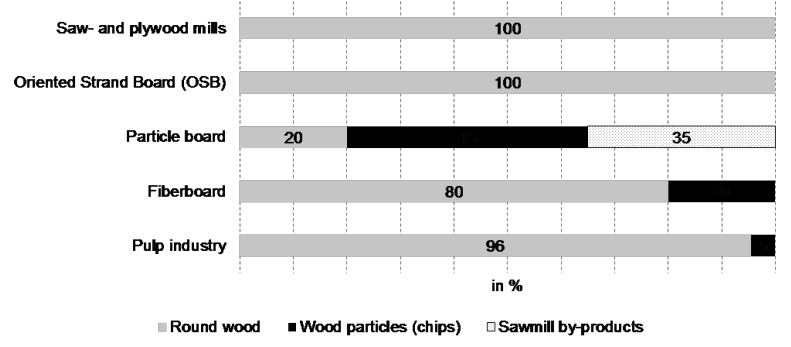

FIGURE 2 Wood resources mix consumption at selected wood industrial segments.).

Panel industries demanded WPR sharing $30 \%$ of their total wood resources consumption. This figure draws attention to the increase on cascading use in this segment, which had required only I5 \% of WPR in the 1990s (Brito, 1995).

All inquired enterprises produced residues in different forms, as presented in Table 8. The occurrence of WPR was calculated according to the processing yield informed on the interviews. Given that volumes on semifinished products and round wood consumption were known, there was also a possibility to disclose WPR occurrence.

It was estimated that around $30 \mathrm{hm}^{3}$ wood residues available in 2009 (Tuoto, 2009)This estimation recorded WPR (91 \%), municipal solid residues (6\%) and municipal pruning residues ( $3 \%)$. If it is considered that the wood residues occurrence increased at the same growth rate of round wood consumption during the observed (around $9.5 \%$ ), at least $33 \mathrm{hm}^{3}$ of wood residues were available in 2018 . 
TABLE 8 Wood processing residues amounts by assortment and wood industrial segments.

\begin{tabular}{ccc}
\hline Segments & Assortment & $\begin{array}{c}\text { Amount } \\
{[\%]}\end{array}$ \\
\hline Sawmill industry & $\begin{array}{c}\text { Sawmill by products, wood chips, edge } \\
\text { trimming }\end{array}$ & $40-55$ \\
Plywood \& veneer & $\begin{array}{c}\text { Peeler core, log conicity, edge trimming } \\
\text { with and without glue content }\end{array}$ & $40-46$ \\
Pulp industry & Black liquor & 50 \\
Panel industry & Edge trimming with glue content & $18-20$ \\
\hline
\end{tabular}

According to the primary survey, the major part of WPR was sold for energy uses and supplied essentially "industry \& farming" demand for heat and power. Even though major part of the available WPR was consumed for energy use, the survey also unveiled other material uses, e.g. on livestock. According to (Ceratto, 2016) for I,000 poults $4.03 \mathrm{~m}^{3}$ of wood shavings are demanded for bedding purposes in Brazil. The reported poultry stock of 14.7 million animals in 2018 (IBGE, 2018c) could had figured as a relevant consumer of WPR for material use. However, the resource balance took into consideration only the hens stock of 246 million animals. Therefore, it was assumed that the hens' population consumed around I million $\mathrm{m}^{3}$ of wood shavings in 2018 , volume $18 \%$ higher than for 2008.

Another niche material use for WPR was represented by the wood plastic composites (WPC) production. However, Brazil had produced WPC during the analysed period information on production's volume was not reliable and does not integrated the calculation. The volumes are expected to be negligible since there is no significant industry in Brazil.

A small amount of WPR was consumed to supply the pellets production. Between 2015 and 2017 pellets production inland had reached a CAGR of $150 \%$. This fact can be related to the directive of the European Parliament (EP, 2009), which had skyrocketed the demand for renewable energy sources. Brazil exported 108 mil tonnes of pellets, which represented $23 \%$ of the national production. Italy and the United Kingdom were the main importers (MDIC, 20I8).

Wood resources were appointed to represent an important role on energy production in Brazil. According to EPE (2018) firewood and charcoal were appointed to share $8.4 \%$ of the domestic energy consumption in 2018. Other renewable energy had supplied $19.837 \mathrm{mil}$ tonnes oil equivalent [toe] in the same year, which of black liquor accounted to $48.2 \%$ (figure 3) (EPE, 20I9).

Of the total round wood consumption in Brazil in $2008,39 \%$ were demanded for energy uses. In 2018 this

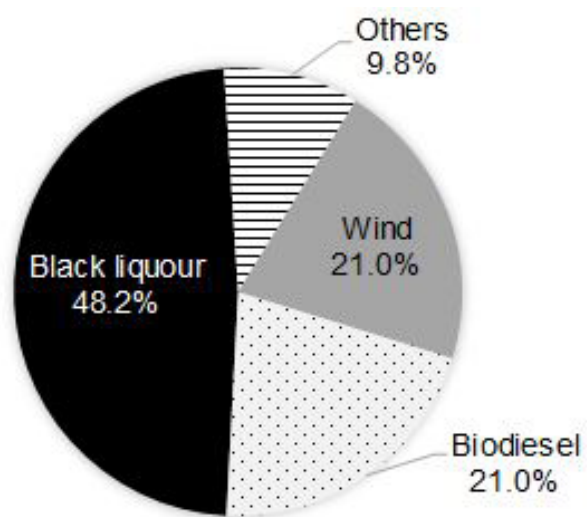

FIGURE 3 Forest cover and the nine forest ecosystem hotspots in Turkey (adapted from (Saygllı, 2016; Şekercioğlu et al., 20I I).

share had decreased by $34 \%$, although the total round wood consumption was greater than ten years before. The increase of WPR consumption for material uses during the analysed period was assumed to be related with livestock growth.

A greater consumption of WPR was appointed to be hindered by several factors. Small and medium scale enterprises appointed the lack of appropriated technologies for residues collection and separation as aggravating factor. According to them, the quality of WPR is essential to enable the value addition and further commercialization. Nonetheless, several enterprises have no knowledge about the infinity of wood products, which demand WPR for its manufacture. Besides that, the high logistic costs due the poor structure of roads and the lack of railways avoid WPR commercialization. Several Brazilian states prohibit the wood waste burning without power generation (State Law SP 12.300/06; MG 18.3031/09; PR 12.493/99; RS 38.356/96). However, these legal measures punishes without clarifying the infinity of wood products, which demand WPR for its manufacture.

The utilization of waste wood from civil construction (demolish), municipal pruning and MSW also faces collection and separation challenges. Even if there is federal legislation to improve the reuse of resources, the reality is a disturbing deficit on recycling of organic residues in Brazil (Zago and Barros, 2019). There is no doubt about the benefits related to the reuse of residues. Cascading can encompasses different activities as recycling, reuse, remanufacture and is, most of the time, a cross-sectoral concept (e.g., spanning across waste management, design, and energy management) (Jarre et al., 2020). The cascading use of wood reduces the impact on climate change and lead to the best use of the resource (Budzinski et al., 2020; Ciccarese et al., 20I4). In specific scenarios, the cascading use of wood 
saves up to $35 \%$ of fresh wood resources(Taskhiri et al., 2019).

Techniques to improve collection and separation of wood waste are essential to improve the cascading use of wood. Clarification around the importance on add value to waste wood is a path to develop a circular economy culture and improve wood resource efficiency.

\section{CONCLUSION}

As a result of the calculation method, where the resource consumption is calculated on the basis of the resource mix sources equals uses in the balance. The volumes on potential round wood production (Table 5; $329.8 \mathrm{hm}^{3} ; 320.8 \mathrm{hm}^{3}$ ) conforms well to the reported round wood consumption in 2018 (Table 4; $229.7 \mathrm{hm}^{3}$ ). The plantation forests supplied $85 \%$ of the domestic round wood consumption (Table $5 ; 272.0 \mathrm{hm}^{3}$ ), avoiding import dependencies. Alternative wood resources as municipal pruning residues and municipal solid waste (e.g. demolish, packages) were not integrated into the resource balance due to lacking data. This draws attention to an even greater potential on wood resources availability. The author suggest further research on techniques for collection and separation of all kinds of wood waste to improve the cascading use and wood resource efficiency.

During the analysed period the wood industry has changed. The evidence from this study suggests the increase on wood resources consumption for energy uses (e.g. pellets, black liquor) from 2008 to 2018. Plywood $\&$ veneer and charcoal production decreased during the analysed period, while pulp and panels industries achieved annually new production records.

The occurrence of WPR increased in volume and gained significance inside and outside the wood industrial segments in Brazil. This fact suggests the improvement on cascading use, where the residues utilization had been diversifying. Even if there was no concern about the competition for wood resources between material and energy uses, a constant monitoring is suggested. There is certainly room for data improvement since natural forests, which cover $57.3 \%$ (figure I) of Brazilian territory, were not included on the WBR. However, it is important to highlight that the 10 million ha of plantation forests currently satisfied the main portion of the domestic demand.

The authors recommends the establishment of more effective actions to improve the cascading use of wood and enhance resource efficiency as e.g. the clarification around the importance of resource efficiency to raises consumer awareness about benefits of cascading use. The payment for correct disposal of wood waste is a good incentive to achieve appropriate collection and separation of residues. If the municipalities receive the duty to reward correct waste disposal and add value to it, they benefit from the generated income. Besides that, the collection, separation and processing of waste achieve job creation and reduce the environmental damage of wood resources utilization. The authors believe that, a comparative analysis between the costs related to cascading use of wood (waste wood collection, separation and processing) and the costs for round wood production from plantation forest is an important future research topic to be taken into consideration.

This study was carried out between 2016 and 2018 before the forest fires occurred in 2019 in Brazil. Although this goes beyond the purpose of this study, we suggest that a transformation of degraded lands (e.g. unproductive agricultural fields) into forests (plantation or assisted natural regeneration) offers an alternative to reduce the use pressure on natural forests.

\section{ACKNOWLEDGEMENTS}

The present study was only possible due to the support of CONSUFOR - Advisory \& Research providing tools, network and knowhow in the Brazilian forest sector.

\section{LIST OF ABBREVIATIONS}

ABIPEL: Associação Brasileira das Indústrias de Pellets

ABRELPE: Associação Brasileira de Empresas de Limpeza Pública e Resíduos Especiais

CAGR: Compound Annual Growth Rate

$\mathrm{cm}$ : centimetres

EPE: Energy Research Office

FAO: Food and Agriculture Organization of the United Nations

FOB: Free on board

FSC: Forest Stewardship Council

GDP: gross domestic product

ha: hectare

HB: hardboard

$\mathrm{hm}^{3}$ : million cubic meters

IBA: Indústria Brasileira de Árvores] 
IBGE: Instituto Brasileiro de Geografia e Estatística

kg: kilogram

$\mathrm{m}^{3}$ : cubic meter

MAl: mean annual increment

MDF: medium density fibreboard

MDIC: Ministério da Indústria, Comércio Exterior e Serviços

MME: Ministério de Minas e Energia

MSW: Municipal solid waste

OSB: oriented strand board

SFB: Brazilian Forest Service

t: tonnes

TIMO: Timber Investment Management Organization

UDS: United states dollar

WPR: wood processing residues

WRB: wood resource balance

\section{REFERENCES}

ABRELPE, 20I7. Panorama dos residuoes sólidos no brasil.

BC, 2019. Conversão de moedas [WWW Document]. URL https://www4.bcb.gov.br/pec/conversao/conversao.asp

BRITO, E.O., 1995. Estimativa da produção de resíduos na indústria brasileira de serrarias e laminação de madeira. Floresta e Ambient. 27-35.

BUDZINSKI, M., BEZAMA, A., THRÄN, D., 2020. Estimating the potentials for reducing the impacts on climate change by increasing the cascade use and extending the lifetime of wood products in Germany. Resour. Conserv. Recycl. X 6, 100034.

CERATTO, V., 2016. A avicultura e a silvicultura [WWW Document]. URL https://www.aviculturaindustrial.com. br/imprensa/a-avicultura-e-a-silvicultura-por-valmorceratto/201 10420-1 15219-m849

CGEE, 2010. Siderurgia no Brasil 2010-2015: Subsídios para tomada de decisão. Brasília.

Ciccarese, L., Pellegrino, P., Pettenella, D., 2014. A new principle of the European Union forest policy: the cascading use of wood products. L'italia For. e Mont. 285-290.

EMBRAPA, 2012. Software for management and economic analysis of forest plantations.
EP, 2009. DIRECTIVE 2009/28/EC OF THE EUROPEAN PARLIAMENT AND OF THE COUNCIL of 23 April 2009 on the promotion of the use of energy from renewable sources and amending and subsequently repealing Directives 200I/77/EC and 2003/30/EC.

EPE, 2019. Brazilian Energy Balance. Brasília.

EPE, 2018. Brazilian Energy Balance. Brasília.

FAO, 2018. Forestry Production and Trade [WWW Document]. URL http://www.fao.org/faostat/en/\#data/FO

FAO, 2016. Global Forest Resources Assessment 20I5. Rome.

FSC, 2019. Facts \& Figures [WWW Document]. URL https:// fsc.org/en/page/facts-figures

GARCIA, D.P., 2017. Cresce a produção de pellets no Brasil. O Pap. 83-84.

IAB, 2018. A siderurgia em números. Rio de Janeiro.

IBA, 2019. Relatório Ibá.

IBGE, 20I8a. Tabela 29I - Quantidade produzida e valor da produção na silvicultura [...]. [WWW Document]. Pesqui. da Extração Veg. e da Silvic. URL https://sidra.ibge.gov.br/ tabela/29l

IBGE, 2018b. Tabela 5930 - Área total existente em 31//2 dos efetivos da silvicultura [...]. [WWW Document]. Pesqui. da Extração Veg. e da Silvic. URL https://sidra.ibge.gov.br/ tabela/5930

IBGE, 2018c. Efetivo dos rebanhos (Cabeças) [WWW Document]. Pesqui. da Pecuária Munic. URL https://sidra. ibge.gov.br/pesquisa/ppm/quadros/brasil/20I8

IBGE, 20I7a. Tabela 3653 - Produção Física Industrial, por seções e atividades industriais [WWW Document]. Pesqui. Ind. Mens. URL https://sidra.ibge.gov.br/tabela/3653

IBGE, 20I7b. Tabela 6636 - Número de estabelecimentos agropecuários [...]. [WWW Document]. Censo Agropecuário. URL https://sidra.ibge.gov.br/pesquisa/ censo-agropecuario/censo-agropecuario-2017

IPEA, 20I2a. Diagnóstico dos resíduos sólidos da construção civil, Relatório de Pesquisa. Brasília.

IPEA, 20I2b. Diagnóstico dos Resíduoes Sólidos Urbanos. Brasília.

IPEA, 2012c. Diagnóstico dos Resíduos Orgânicos do Setor Agrossilvopastoril e Agroindústrias Associadas. Brasília.

IPT, n.d. Informações sobre madeiras [WWW Document]. URL https://www.ipt.br/consultas_online/informacoes_sobre_ madeira/busca 
JARRE, M., PETIT-BOIX, A., PRIEFER, C., MEYER, R., LEIPOLD, S., 2020. Transforming the bio-based sector towards a circular economy - What can we learn from wood cascading? For. Policy Econ. I 10, 101872.

MANTAU, U., BLANKE, C., 2016. Status of cascading use in the EU. In: Vis M., U. Mantau, B. Allen (Eds.) (2016) Study on the optimised cascading use of wood. No 394/PP/ENT/ $\mathrm{RCH} / \mathrm{I4/7689.} \mathrm{Brussels.}$

MANTAU, U., SAAL, U.S., PRINS, K., STEIERER, F., LINDNER, M., VERKERK, H., EGGERS, J., LEEK, N., OLDENBURGER, J., ASIKAINEN, A., ANTTILA, P., 20I0. Real potential for changes in growth and use of EU forests.

MDIC, 2018. Comex Stat: Exportação e Importação Geral [WWW Document]. URL http://comexstat.mdic.gov.br/pt/ geral (accessed 2.11.19).

PIKETTY, M.-G., WICHERT, M., FALLOT, A., AIMOLA, L., 2009. Assessing land availability to produce biomass for energy: The case of Brazilian charcoal for steel making. Biomass and Bioenergy 33, 180-190.

PINTO, R.G.D., Szklo, A.S., Rathmann, R., 2018. CO2 emissions mitigation strategy in the Brazilian iron and steel sector- From structural to intensity effects. Energy Policy I I4, 380-393.

SAAL, U., WEIMAR, H., MANTAU, U., 20I7. Wood Processing Residues, in: Advances in Biochemical Engineering/ Biotechnology. pp. 27-4I.
SFB, 2019. Brazilian Forests as a glance. Brasília.

SFB, 2018. Boletim SNIF.

SICSÚ, A.B., LIMA, J.P.R., 20I3. Fronteiras agrícolas no Brasil. Nov. Econ. 10, 109-138.

SILVA, C.A.F. E, BUENO, J.M., NEVES, M.D., 2017. A indústria de celulose e papel no Brasil. O Pap. 16-28.

SILVA, C.A.F. E, BUENO, J.M., NEVES, M.R., 20I5. A indústria de celulose e papel no Brasil. O Pap. 20-32.

STCP, 2000. Consumo específicos médios obtidos na transformação da matéria-prima florestal [WWW Document]. URL http://ambienteduran.eng.br/fatores-deconversao

TASKHIRI, M.S., JESWANI, H., GELDERMANN, J., AZAPAGIC, A., 2019. Optimising cascaded utilisation of wood resources considering economic and environmental aspects. Comput. Chem. Eng. 124, 302-316.

TUOTO, M., 2009. Levantamento sobre a geracao de resíduos provenientes da atividade madeireira e proposicao de diretrizes para políticas, normas e condutas técnicas para promover o uso adequado.

ZAGO, V.C.P., BARROS, R.T. DE V., 2019. Management of solid organic waste in brazil: From legal ordinance to reality. Eng. Sanit. e Ambient. 24, 219-228. 